\title{
Morphological characterization of active germoplasm bank fig tree accessions
}

\author{
Maria Gabriela Fontanetti Rodrigues ${ }^{1}$, Tatiane Paes dos Santos ${ }^{2}$, Antonio Flávio Arruda Ferreira ${ }^{3}$, \\ Laís Naiara Honorato Monteiro ${ }^{4}$, Eduarda Sayuri Nakanishi ${ }^{5}$, Aparecida Conceição Boliani ${ }^{6}$
}

\begin{abstract}
Fig tree (Ficus carica L.) is a fruit of great importance worldwide, being able to be implanted as new source of agricultural variability. The aim of the present work was to characterize the active germplasm bank of fig trees by means of morphological descriptors of 45 fig accessions at the Faculty of Agrarian and Technological Sciences, Campus of Dracena, FCAT / UNESP aiming at the recognition of the quality and genetic variability potential of the species. Thus, their biometric characteristics were evaluated by qualitative and quantitative descriptors of leaves and fruits. Fig tree accessions were characterized by means of the morphological characteristics of leaves and fruits, identifying AGB with high phenotypic variability and well adapted to the region and, by the analysis of the qualitative and quantitative characteristics, it was concluded that the most divergent accessions presented characteristics of agronomic interest, allowing the selection of features in order to subsidize conservation works, genetic improvement and crop production. Index terms: Ficus carica L., ex situ conservation, genetic resources, biometrics.
\end{abstract}

\section{Caracterização morfológica de acessos de banco ativo de germoplasma de figueira}

Corresponding author: maria.gf.rodrigues@unesp.br

Received: April 25, 2019 Accepted: July 11, 2019

Copyright: All the contents of this journal, except where otherwise noted, is licensed under a Creative Commons Attribution License.

\begin{abstract}
Resumo- A figueira (Ficus carica L.) é uma frutífera de grande importância mundial, podendo ser implantada como fonte de variabilidade agrícola. Diante disso, o objetivo do presente trabalho foi realizar a caracterização do banco ativo de germoplasma da cultura da figueira por meio de descritores morfológicos de 45 acessos de figo, na Faculdade de Ciências Agrárias e Tecnológicas, Câmpus de Dracena, FCAT/UNESP, visando ao reconhecimento da qualidade e da potencialidade da variação genética da espécie. Assim, foram avaliadas características biométricas por descritores qualitativos e quantitativos de folhas e de frutos. Foi possível caracterizar os acessos de figueira por meio das características morfológicas de folhas e de frutos, identificando um BAG com alta variabilidade fenotípica e bem adaptado à região e, pela análise dos caracteres qualitativos e quantitativos, conclui-se que os acessos mais divergentes apresentaram características de interesse agronômico, possibilitando a seleção de caracteres a fim de subsidiar trabalhos de conservação, de melhoramento genético e de produção da cultura.
\end{abstract}

Termos para indexaçao: Ficus carica L., conservação ex situ, recursos genéticos, biometria.

PhD Professor, Faculty of Agrarian and Technological Sciences, FCAT / UNESP, Campus of Dracena, São Paulo, Brasil. E-mail: maria. gf.rodrigues@unesp.br (ORCID: 0000-0003-1235-7376)

${ }^{2}$ Agronomist, FCAT / UNESP, Campus of Dracena. São Paulo, Brasil. E-mail: tatipaes_9@hotmail.com ${ }^{\text {(ORCID: 0000-0003-4209-7536) }}$ ${ }^{3} \mathrm{PhD}$ Professor, State University of Mato Grosso, Campus of Alta Floresta, Mato Grosso, Brasil . E-mail: arrudaferreira.af@gmail.com ${ }^{\text {(ORCID: }}$ 0000-0002-5879-8794)

${ }^{4} \mathrm{MSc}$, Faculty of Agrarian Sciences, FCA / UNESP, Campus of Botucatu, São Paulo, Brasil E-mail: laismonteiiro@gmail.com (ORCID 0000-00016847-5190)

${ }^{5}$ Degree in Agronomic Engineering, FCAT / UNESP, Campus of Dracena, São Paulo, Brasil E-mail: eduarda.sayurii@hotmail.com ${ }^{\text {(ORCID: }}$ $0000-0002-3694-4340)$

${ }^{6} \mathrm{PhD}$, Faculty of Engineering of Ilha Solteira, FEIS / UNESP, Campus of Ilha Solteira, São Paulo, Braisl. E-mail: boliani@agr.feis.unesp.br (ORCID: 0000-0003-1447-949-x) 


\section{Introduction}

Fig (Ficus carica L.) is among the twenty main fruits exported by Brazil and has maintained third position in the ranking of marketed volume among temperate climate fruits, with production of approximately 26 thousand tonnes per year in 2,600 hectares of planted area, ranking ninth in terms of world production (FAOSTAT, 2019).

However, in Brazil, there is predominance of a single fig-tree cultivar, 'Roxo-de-Valinhos', resulting in serious problems related to pests and diseases, which compromise cultivation and damage fruits, reducing profits, hampering plant development and demanding high expenses with inputs and cultural treatments (FERRAZ, 2017).

Thus, studies aimed at finding solutions to some of these problems would make an enormous contribution for the development of the fig tree crop, being variety diversification, with the use of resistant cultivars and adapted to different environments, an important strategy for the development of the fig culture.

According to Frankham (2005), genetic diversity has become the key to species survival and adaptation to changes in the environment, and the elucidation of the mechanisms of origin and maintenance of this variation is essential (PLATT et al., 2010; HUANG et al., 2014).

He et al. (2016) emphasize the importance of maintaining accessions available in Active Germplasm Banks (AGBs) for the crop, as well as measures for their conservation, which should be implemented in different populations according to their potential to adapt to future climate and environmental changes induced by man.

According to Ramalho et al. (2012), in addition to its conservation and maintenance, the correct characterization of existing AGBs is essential, allowing the recognition of the quality and potentiality of germplasm under the most varied aspects, since they play a fundamental role in the preservation of the genetic variability.

The availability of plant genetic resources necessarily involves the morphological characterization of accessions registered in germplasm banks through the knowledge of a series of data aiming to describe them by means of characteristics of interest, including culture attributes or traits, establishing an identity for each component (VALOIS et al., 2001).

In view of the above, the aim of the present work was to perform the morphological characterization of leaves and fruits of 45 fig tree accessions (Ficus carica L.) of the Active Germplasm Bank introduced at the Faculty of Agrarian and Technological Sciences, Campus of Dracena, FCAT / UNESP, through quantitative and qualitative descriptors.

\section{Material and methods}

The genetic material was composed of 45 Ficus sp. accessions belonging to the one-year-old Active Germplasm Bank of the Agricultural Sector of the Faculty of Agrarian and Technological Sciences FCAT / UNESP, Campus of Dracena-SP.

The experimental design was randomized blocks, consisting of 45 treatments, each accession being considered a treatment, with two blocks and three plants per plot, totaling 270 plants, grown in $1.5 \mathrm{~m} \mathrm{x} 1.5$ $\mathrm{m}$ spacing. Treatments evaluated, with their respective accessions and places of origin, are presented in Table 1 .

Fertilization was performed according to soil analysis and recommendations of Raij et al. (1997), in the projection of fig tree canopies, with soil lacking mulch.

Phytosanitary treatment was carried out with biweekly applications of Bordeaux mixture (1\%) and Mancozeb (200 g p.c./100 liters of water) for the control mainly of fig leaf rust (Cerotelium fici Cast.), alternately applied.

Whenever necessary, weed control was performed by weeding, and irrigation by drip tape three times a week with average precipitation of $2.0 \mathrm{~mm} / \mathrm{h}$ and a $50 \mathrm{~cm}$ wide strip in the planting line.

For the morphological characterization of leaves, branches from the median region of plants were selected and three axillary leaves close to the first fruit were photo-documented, and the following evaluations were performed:

a) Number of lobes per leaf;

b) Length and width of the leaf blade, in centimeters;

c) Petiole length, in centimeters.

For fruit characterization, four fruits at the beginning of maturation from each plant of the experiment were used for the following evaluations:

a) Shape of each fruit: elongate, pyriform oblong or oval;

b) Length and diameter of the median region of each fruit, in centimeter, with the aid of a pachymeter;

c) Length of the peduncle, in centimeter, from its insertion in the stem to the support of syicons.

d) Open or closed ostiole, considering the possibility of visualizing or not the inside of the fruit.

e) The pulp color of each fruit: red, pink or amber. From the biometric results obtained, statistical analysis of all accessions was performed, grouping the averages obtained by the Scott-Knott test at 5\% probability level. Statistical analyses were performed using the Sisvar software: a computer statistical analysis system, version 5.6 (FERREIRA, 2014). 


\section{Results and discussion}

\section{Morphological Characterization of Leaves}

Biometric markers have an extreme ecological value, helping to determine the variability of the species and making it possible to differentiate phenotypic parameters among individuals of a given population, which is one of the most important sources of variability available for plant breeding (PALACE et al. 2016, STOJANOVIĆ et al., 2016).

Leaf biometric markers exhibit drastic shape variation within the same species, reflecting both the heteroblastic development of the apical meristem from which they are derived and the ontogeny of individual leaves as they expand alometrically (CHITWOOD et al., 2016).

Figure 1 shows that most accessions followed the pattern of the 'Roxo-de-Valinhos' cultivar (Figure 2-D), with differentiation in the pronunciation of the 2 secondary lobes. According to Medeiros (2002), the 'Roxo-deValinhos' cultivar is characterized by presenting large leaves with five large and two smaller lobes; dark green color; compact texture, somewhat rigid; creased margin; petiole sinus in the form of lyre and long petiole.

However, a large variation in the number of lobes among certain fig tree accessions was observed, varying from 3 little pronounced large lobes, as occurs in the 'Troyano' variety (Accession 17), represented in Figure 2-A; 3 well pronounced large lobes added of 2 little pronounced lobes, observed in 'Nazaret' cultivar (Access 24), represented in Figure 2-B.

Up to 7 large well-defined lobes added of two small well-pronounced lobes were also found, as on the case of 'Preto de Piracicaba Fig' accession (Accession 44), Figure 2-E.

There is large variation in the number of leaf lobes among AGB fig tree accessions and differences regarding how pronounced these lobes were presented. As for the length and width of leaves, accessions 5, 28, 25, 6, 16 and 45 stood out. Accession 45 (Turco Fig) presented the highest length and width values $(25.7 \mathrm{~cm}$ and $23.3 \mathrm{~cm}$, respectively) of leaves (Figure 2-C), being statistically superior to the other accessions (Table 2).

Accessions with the lowest length and width values were $20,15,26,24,23,1,21,3$ and 27 , which, in principle, would lead plants to have smaller photosynthetic area, and, consequently, lower growth and development, as is the case of accessions 20,23, 24 and 26, which stood out for the lowest effective height values.

According to Chitwood and Otoni (2017), working with leaf morphology in Passiflora species, leaf shape diversity is considered a profound change in differentiation that causes the development of the primary vasculature pattern and laminar expansion.
Each of the aspects of leaf morphology provides different points of view about its pattern, and the number of lobes is a highly relevant factor for the differentiation of "toothed" plants, as is also the case with the fig tree, which proved to be promising feature of selection of leaf morphology among the features evaluated by Rodrigues et al. (2017), because it presents high heritability and high genetic correlation, being little influenced by the environment.

Plants present different responses regarding tolerance to shading, reflecting on growth and development (PAEZ et al., 2000). Luminosity is one of the limiting factors for plant development, since the edaphoclimatic conditions of the environment are reflected in the growth and in the different forms of adaptation (Andrade et al., 2004).

Thus, growth efficiency may be related to the ability of plants to adapt to light conditions, and the satisfactory growth of some species in low or high luminosity environments is attributed to their ability to rapidly adjust their biomass allocation model and physiological behavior (DIAS-FILHO 1997).

Thus, for the other accessions that presented small leaves, this deficiency in the photosynthetic area, individually, may have been supplied by the greater number of active leaves in plants, since, in addition to individual leaf area, the number and angle of leaves alter the light distribution within the plant and, consequently, influence the self-shading inside the canopy (FALSTER and WESTOBY, 2003, SARLIKIOTI et al., 2011, CHEN et al., 2014).

Table 2 shows the leaf length and width values of all accessions, together with their statistical analysis, which obtained average of $17.0 \mathrm{~cm}$ for length and 14.9 $\mathrm{cm}$ for width, with variation coefficient VC (\%) of 15.87 and 15.02 , respectively.

According to Perez et al. (1988), the efficiency with which plant intercepts solar radiation also depends on other architectural features involved in the threedimensional (3-D) arrangement of leaves, such as internode length (DAUZAT et al., 2008; Silva et al., 2014; CHEN et al., 2014), petiole length (TAKENAKA, 1994; CHENU et al., 2005) and branch patterns (NIINEMETS, 2007; SILVA et al., 2014).

However, for leaf petiole length, in spite of a great variation among accessions, from $4.2 \mathrm{~cm}$ to $10.0 \mathrm{~cm}$, except for accession 45 (Turco Fig), which presented larger petiole and both length and width statistically higher than the other accessions, its length had no relation to the length and width of leaves, which can be observed in Table 2, with mean of $6.8 \mathrm{~cm}$ and variation coefficient $\mathrm{VC}(\%)$ of 19.5 . 


\section{Morphological Characterization of Fruits}

The shape of fruits of the 45 Ficus sp. accessions were varied, from elongated to oval, which were already expected; however, the flattened shape of fruits was also observed. In this case, fruits with diameter significantly larger than their length were considered flattened, with abrupt ostiole area, such as, for example, accessions 8 and 9, which represent the 'White Genova' cultivar (Figure 3 -D) of different regions, with mean length and width values, respectively, of 32.5-38.8 $\mathrm{mm}$ and $32.0-37.1 \mathrm{~mm}$.

Among accessions considered flattened, accessions 28, 29, 30, 31, 32, 35 and 36 were still at an immature stage of development, not reaching their full physiological development, being discolored, with shape and density different from a mature fruit, weighting three times less than the mature fig (VENDRUSCOLO, 1988). The physiological maturity point depends on the species, as it is affected by genetic factors and also by environmental factors such as temperature and relative humidity, and the knowledge of the maturation process is important for the establishment of the ideal harvesting point (SILVA, 2009).

Oval shape (Figure -A) was observed in 'Bonato', 'Smyrna', and 'Pingo de Mel' cultivars, considered as characteristic of parthenocarpic fruits. In the case of 'Smyrna' cultivar in particular, its shape tends to change due to the caprification process, indispensable for the normal development of fruits of this pomological class (ARADHYA, DIANNE VELASCO and KOEHMSTEDT, 2010), which does not occur in Brazil.

Still with respect to the shape of fruits, length and diameter measures, simultaneously, define this parameter. For the length of fruits, the highest values were observed for accessions 4, 8, 19, 22, 23 and 37. For diameter, accessions 4, 8, 9 and 22 stood out, with the production of fruits already at the beginning of the maturation stage.

In the specific case of accession 19 - Plant 440 and 23 - Plant 301, elongated shape was observed, which is in agreement with descriptions of Rodrigues et al. (2012). An elongated fruit shape is defined as a fruit with its length significantly larger than its diameter; in this case, with mean values of $34.3 \mathrm{~mm}$ and $28.5 \mathrm{~mm}$, respectively, which can be observed in Figure 3-B.

Rodrigues et al. (2012), working with selection of mutants in fig plants formed by stakes irradiated with gamma rays, observed that the main commercial cultivar, 'Roxo-de-Valinhos' (Accession 4), 'White Genova' and Accession 22, which represents Plant 214 of that experiment, presented the same characteristics observed in the present work.

'Roxo-de-Valinhos' cultivar has predominance of fruits with oblong-pyriform shape (Figure 3-C), with short and thick neck, almost without limit of separation with body from the receptacle, as described by Rigitano
(1955). This shape was the one that prevailed among AGB fig tree fruits under study, as can be observed in Figure 4, which demonstrates the distinction among fruits of accessions that compose Ficus sp. AGB.

The distribution of accessions, according to the length and diameter of fruits, is described in Table 3. The average values obtained were $28.4 \mathrm{~mm}$ for length and $28.3 \mathrm{~mm}$ for width with variation coefficient VC (\%) of 11.3 and 11.4, respectively. The highest fruit length was observed for 'Roxo-de-Valinhos' cultivar (Accession 4), with $35.3 \mathrm{~mm}$ and the highest width for accessions 8 and 9 (White Genova), with 37.1 and $38.8 \mathrm{~mm}$.

Still in Table 3, accession 16 (Palestino) presented the largest peduncle $(4.0 \mathrm{~mm})$. Large peduncle in fruits is an interesting agronomic characteristic for Ficus sp. production, because it facilitates harvest (SONG et al., 2016), and increases the shelf life of fruits. According to Carvalho et al. (2008), large peduncle is related to genotype, and presents high heritability index in the restricted sense, being a characteristic of early selection.

In the specific case of the fig tree crop, a very important aspect to determine the quality of fruits, in addition to the size of fruits, is the small ostiole opening (ALJANE and NAHDI, 2018), which reduces the incidence of pests and avoids the depreciation of fruits with possible peel cracks. The ostiole is characterized as the opening for the entrance of the Blastophaga psene wasp so that inflorescence pollination within the siconium can occur for the development of fig fruits (LAMAS et al., 2009). However, in addition to the fact that this wasp does not occur in Brazil due to climatic reasons, the fig fly (Zaprionus indianus Gupta, 1970) uses this hole for feeding and laying eggs (RAGA, 2002; RAGA and SOUZA FILHO, 2003), which causes fruit depreciation during production and marketing due to very severe damage.

One of the ways to prevent the entry of this pest within siconium is the selection of fig plants showing ostiole opening the less pronounced as possible (Figure 5 ), as is the case of accession 2 (Nobile), 3 (Genovesco), 6 (Adriatic White), 7 (Bonato), 11 (Smyrna), 14 (Pingo de Mel), 16 (Palestino), 17 (Troyano), 18 (Vermelho de Piracicaba Fig), 21 (Plant 189), 25 (Cuello Negro), 40 (Caprifig) and 43 (Mini Fig), as can be seen in Figure 6, which demonstrates the distribution of AGB fig accessions according to the opening of this hole. In the case of accession 21, which represents Plant 189, it maintained the characteristic of null ostiole opening, as observed by Rodrigues et al. (2012).

The other accessions that were considered with closed ostiole and that were not considered, presented white color of the internal siconium cavity (Figure 8-A), which characterizes fruit immaturity due to late maturation.

Regarding fruit coloration evaluation, the majority of accessions maintained the common reddish- 
pink coloration, as can be observed in Figure 7. However, amber (Figure 8-B) and intense red colorations (Figure 8-C) were verified in some accessions, such as accessions 18 (Vermelho de Piracicaba Fig) and 23 (Plant 301), identified with more reddish coloration than the fruits of the other accessions.
The amber coloration was observed in accessions 2 (Nobile), 5 (Stanford), 6 (Adriático Branco), 10 and 11 (Smyrna), 14 (Pingo de Mel) and 40 (Caprifig), and unlike Nóbile, Adriatico Branco and Pingo-de-Mel, which present this characteristic coloration, need pollination to develop their fruits.

Table 1. Active Germplasm Bank Fig tree accessions of the Faculty of Agricultural and Technological Sciences (FCAT / UNESP). Dracena / SP, 2017.

\begin{tabular}{|c|c|c|}
\hline Tratament & Acession & Place of Origin \\
\hline 1 & Calimyrna & São José do Rio Preto \\
\hline 2 & Nobile & IAC $^{1}$ \\
\hline 3 & Genovesco & $\mathrm{IAC}^{1}$ \\
\hline 4 & Roxo-de-Valinhos A & São Sebastião do Paraíso \\
\hline 5 & Stanford & $\mathrm{IAC}^{1}$ \\
\hline 6 & White Adriatic & $\mathrm{IAC}^{1}$ \\
\hline 7 & Bonato & $\mathrm{IAC}^{1}$ \\
\hline 8 & White Genova A & São José do Rio Preto \\
\hline 9 & White Genova B & $\mathrm{IAC}^{1}$ \\
\hline 10 & Smyrna A & $\mathrm{IAC}^{1}$ \\
\hline 11 & Smyrna B & São José do Rio Preto \\
\hline 12 & Brunswich & $\mathrm{IAC}^{1}$ \\
\hline 13 & Caprifig A & $\mathrm{IAC}^{1}$ \\
\hline 14 & Pingo de Mel & Ilha Solteira \\
\hline 15 & Roxo-de-Valinhos Gigante & Ilha Solteira \\
\hline 16 & Palestino & Campinas \\
\hline 17 & Troyano & $\mathrm{IAC}^{1}$ \\
\hline 18 & Vermelho & Piracicaba \\
\hline 19 & PI 440 & Ilha Solteira \\
\hline 20 & PI 433 & Ilha Solteira \\
\hline 21 & PI 189 & Ilha Solteira \\
\hline 22 & PI 214 & Ilha Solteira \\
\hline 23 & PI 301 (trat6) & Ilha Solteira \\
\hline 24 & Nazaret & Espanha \\
\hline 25 & Cuello Negro & Espanha \\
\hline 26 & Roxo-de-Valinhos B & Ilha Solteira \\
\hline 27 & Acesso 27 & Monte Alto \\
\hline 28 & Acesso 28 & Monte Alto \\
\hline 29 & Acesso 29 & Monte Alto \\
\hline 30 & Acesso 30 & Monte Alto \\
\hline 31 & Acesso 31 & Monte Alto \\
\hline 32 & Acesso 32 & Monte Alto \\
\hline 33 & Acesso 33 & Monte Alto \\
\hline 34 & Acesso 34 & Monte Alto \\
\hline 35 & Acesso 35 & Monte Alto \\
\hline 36 & Acesso 36 & Monte Alto \\
\hline 37 & Acesso 47 & Bahia \\
\hline 38 & Acesso 44 & Piracicaba \\
\hline 39 & Acesso 46 & Piracicaba \\
\hline 40 & Caprifig B & Ilha Solteira \\
\hline 41 & Acesso 41 & Monte Alto \\
\hline 42 & Acesso 42 & Monte Alto \\
\hline 43 & Mini Figo & $\mathrm{IAC}^{1}$ \\
\hline 44 & Preto & Piracicaba \\
\hline 45 & Turco & Campinas \\
\hline
\end{tabular}

${ }^{1}$ IAC = Agronomic Research Institute, APTA Fruit Center, Jundiaí / SP. 
Table 2- Petiole length (CP), length (CF) and width (LF) of leaves of Active Germplasm Bank fig accessions of the Faculty of Agricultural and Technological Sciences (FCAT / UNESP). Dracena / SP, 2017

\begin{tabular}{|c|c|c|c|}
\hline Tratament & $\mathrm{CP}(\mathrm{cm})$ & CF (cm) & LF (cm) \\
\hline 1 & $5,42 \mathrm{C}$ & $12,58 \mathrm{E}$ & $12,17 \mathrm{D}$ \\
\hline 2 & $7,50 \mathrm{~B}$ & $15,58 \mathrm{D}$ & $14,42 \mathrm{D}$ \\
\hline 3 & 7,17 B & $13,00 \mathrm{E}$ & $12,33 \mathrm{D}$ \\
\hline 4 & $7,42 \mathrm{~B}$ & $18,00 \mathrm{C}$ & $16,08 \mathrm{C}$ \\
\hline 5 & $5,75 \mathrm{C}$ & $21,00 \mathrm{~B}$ & 19,92 B \\
\hline 6 & $6,83 \mathrm{~B}$ & $22,92 \mathrm{~B}$ & $19,58 \mathrm{~B}$ \\
\hline 7 & $4,88 \mathrm{D}$ & $17,42 \mathrm{C}$ & $16,55 \mathrm{C}$ \\
\hline 8 & $7,92 \mathrm{~B}$ & $18,38 \mathrm{C}$ & $17,72 \mathrm{C}$ \\
\hline 9 & $7,92 \mathrm{~B}$ & $18,75 \mathrm{C}$ & $16,58 \mathrm{C}$ \\
\hline 10 & $7,55 \mathrm{~B}$ & $18,08 \mathrm{C}$ & $15,97 \mathrm{C}$ \\
\hline 11 & $7,22 \mathrm{~B}$ & $15,83 \mathrm{D}$ & $15,22 \mathrm{C}$ \\
\hline 12 & $5,83 \mathrm{C}$ & $17,50 \mathrm{C}$ & $15,67 \mathrm{C}$ \\
\hline 13 & $5,67 \mathrm{C}$ & $18,58 \mathrm{C}$ & $16,92 \mathrm{C}$ \\
\hline 14 & $6,17 \mathrm{C}$ & $16,63 \mathrm{D}$ & $15,42 \mathrm{C}$ \\
\hline 15 & $4,27 \mathrm{D}$ & $12,00 \mathrm{E}$ & $12,27 \mathrm{D}$ \\
\hline 16 & 7,33 B & $23,52 \mathrm{~B}$ & $18,17 \mathrm{~B}$ \\
\hline 17 & $6,13 \mathrm{C}$ & $20,25 \mathrm{C}$ & $17,50 \mathrm{C}$ \\
\hline 18 & $7,67 \mathrm{~B}$ & $16,92 \mathrm{D}$ & $14,08 \mathrm{D}$ \\
\hline 19 & $6,17 \mathrm{C}$ & $15,50 \mathrm{D}$ & $12,75 \mathrm{D}$ \\
\hline 20 & $7,00 \mathrm{~B}$ & $11,00 \mathrm{E}$ & $11,50 \mathrm{D}$ \\
\hline 21 & $4,50 \mathrm{D}$ & $13,00 \mathrm{E}$ & $12,50 \mathrm{D}$ \\
\hline 22 & $7,50 \mathrm{~B}$ & $15,00 \mathrm{D}$ & $13,00 \mathrm{D}$ \\
\hline 23 & $7,00 \mathrm{~B}$ & $12,50 \mathrm{E}$ & $12,00 \mathrm{D}$ \\
\hline 24 & $6,00 \mathrm{C}$ & $12,00 \mathrm{E}$ & $10,50 \mathrm{D}$ \\
\hline 25 & $7,00 \mathrm{~B}$ & $22,00 \mathrm{~B}$ & $15,00 \mathrm{C}$ \\
\hline 26 & $5,00 \mathrm{D}$ & $12,00 \mathrm{E}$ & $9,00 \mathrm{D}$ \\
\hline 27 & $6,42 \mathrm{C}$ & $13,17 \mathrm{E}$ & $12,33 \mathrm{D}$ \\
\hline 28 & $8,75 \mathrm{~A}$ & $21,58 \mathrm{~B}$ & $18,92 \mathrm{~B}$ \\
\hline 29 & $7,80 \mathrm{~B}$ & $19,17 \mathrm{C}$ & $15,88 \mathrm{C}$ \\
\hline 30 & $9,00 \mathrm{~A}$ & $18,75 \mathrm{C}$ & $17,00 \mathrm{C}$ \\
\hline 31 & $9,67 \mathrm{~A}$ & $19,83 \mathrm{C}$ & $17,00 \mathrm{C}$ \\
\hline 32 & $7,38 \mathrm{~B}$ & $16,08 \mathrm{D}$ & $14,75 \mathrm{C}$ \\
\hline 33 & $7,25 \mathrm{~B}$ & $19,83 \mathrm{C}$ & $16,50 \mathrm{C}$ \\
\hline 34 & $5,08 \mathrm{D}$ & $15,00 \mathrm{D}$ & $11,50 \mathrm{D}$ \\
\hline 35 & $8,67 \mathrm{~A}$ & $19,33 \mathrm{C}$ & $16,25 \mathrm{C}$ \\
\hline 36 & $6,75 \mathrm{~B}$ & $15,25 \mathrm{D}$ & $14,92 \mathrm{C}$ \\
\hline 37 & $7,83 \mathrm{~B}$ & $19,00 \mathrm{C}$ & $16,33 \mathrm{C}$ \\
\hline 38 & $7,00 \mathrm{~B}$ & $15,67 \mathrm{D}$ & $13,25 \mathrm{D}$ \\
\hline 39 & $5,83 \mathrm{C}$ & $14,58 \mathrm{D}$ & $11,17 \mathrm{D}$ \\
\hline 40 & $4,75 \mathrm{D}$ & $18,83 \mathrm{C}$ & $15,75 \mathrm{C}$ \\
\hline 41 & $6,77 \mathrm{~B}$ & $14,50 \mathrm{D}$ & $12,00 \mathrm{D}$ \\
\hline 42 & $7,83 \mathrm{~B}$ & $17,00 \mathrm{D}$ & $14,92 \mathrm{C}$ \\
\hline 43 & $4,42 \mathrm{D}$ & $15,25 \mathrm{D}$ & $13,83 \mathrm{D}$ \\
\hline 44 & $6,50 \mathrm{C}$ & $16,50 \mathrm{D}$ & $13,92 \mathrm{D}$ \\
\hline 45 & $10,00 \mathrm{~A}$ & $25,77 \mathrm{~A}$ & $23,27 \mathrm{~A}$ \\
\hline V.C. $(\%)$ & 19,50 & 15,87 & 15,02 \\
\hline General mean & 6,81 & 17,00 & 14,94 \\
\hline
\end{tabular}

* Equal letters between lines do not differ by the Scott-Knott test at $5 \%$ probability. 
Table 3. Peduncle length (CPE), length (CFR) and width (LFR) of fruits of Active Germplasm Bank fig accessions of the Faculty of Agricultural and Technological Sciences (FCAT / UNESP). Dracena / SP, 2017.

\begin{tabular}{|c|c|c|c|}
\hline Tratament & CPE (cm) & CFR (cm) & LFR (cm) \\
\hline 1 & 7.97 D & $28.55 \mathrm{C}$ & $22.83 \mathrm{E}$ \\
\hline 2 & $11.13 \mathrm{D}$ & $30.53 \mathrm{~B}$ & $25.47 \mathrm{D}$ \\
\hline 3 & $9.03 \mathrm{D}$ & $29.73 \mathrm{~B}$ & $28.55 \mathrm{D}$ \\
\hline 4 & $9.60 \mathrm{D}$ & $35.28 \mathrm{~A}$ & $34.85 \mathrm{~B}$ \\
\hline 5 & $10.38 \mathrm{D}$ & $24.80 \mathrm{D}$ & $25.95 \mathrm{D}$ \\
\hline 6 & $3.37 \mathrm{E}$ & $23.53 \mathrm{D}$ & $27.72 \mathrm{D}$ \\
\hline 7 & $9.17 \mathrm{D}$ & $25.33 \mathrm{D}$ & $22.62 \mathrm{E}$ \\
\hline 8 & $14.70 \mathrm{C}$ & $32.55 \mathrm{~A}$ & $38.77 \mathrm{~A}$ \\
\hline 9 & $15.48 \mathrm{C}$ & $32.02 \mathrm{~B}$ & $37.07 \mathrm{~A}$ \\
\hline 10 & $14.85 \mathrm{C}$ & $29.30 \mathrm{~B}$ & $28.97 \mathrm{C}$ \\
\hline 11 & $15.98 \mathrm{C}$ & $25.58 \mathrm{D}$ & $22.72 \mathrm{E}$ \\
\hline 13 & $5.78 \mathrm{E}$ & $22.47 \mathrm{D}$ & $25.58 \mathrm{D}$ \\
\hline 14 & $17.67 \mathrm{~B}$ & $28.30 \mathrm{C}$ & $26.18 \mathrm{D}$ \\
\hline 15 & $13.05 \mathrm{C}$ & $23.63 \mathrm{D}$ & $23.13 \mathrm{E}$ \\
\hline 16 & $30.97 \mathrm{~A}$ & $32.30 \mathrm{~B}$ & $29.80 \mathrm{C}$ \\
\hline 17 & $21.08 \mathrm{~A}$ & $29.65 \mathrm{~B}$ & $28.03 \mathrm{D}$ \\
\hline 18 & $14.72 \mathrm{C}$ & $31.12 \mathrm{~B}$ & $26.85 \mathrm{D}$ \\
\hline 19 & $16.42 \mathrm{C}$ & $34.33 \mathrm{~A}$ & $28.48 \mathrm{D}$ \\
\hline 21 & $14.62 \mathrm{C}$ & $30.50 \mathrm{~B}$ & $29.37 \mathrm{C}$ \\
\hline 22 & $14.38 \mathrm{C}$ & $32.97 \mathrm{~A}$ & $33.57 \mathrm{~B}$ \\
\hline 23 & $9.00 \mathrm{D}$ & $33.73 \mathrm{~A}$ & $32.97 \mathrm{C}$ \\
\hline 25 & $12.07 \mathrm{C}$ & $27.37 \mathrm{C}$ & $20.17 \mathrm{E}$ \\
\hline 26 & $8.00 \mathrm{D}$ & $32.00 \mathrm{~B}$ & $31.20 \mathrm{C}$ \\
\hline 27 & $3.70 \mathrm{E}$ & $24.72 \mathrm{D}$ & $26.48 \mathrm{D}$ \\
\hline 28 & $6.65 \mathrm{E}$ & $27.33 \mathrm{C}$ & $30.35 \mathrm{C}$ \\
\hline 29 & $6.73 \mathrm{E}$ & $25.80 \mathrm{D}$ & $30.58 \mathrm{C}$ \\
\hline 30 & $5.92 \mathrm{E}$ & $25.38 \mathrm{D}$ & $27.07 \mathrm{D}$ \\
\hline 31 & $7.63 \mathrm{D}$ & $27.00 \mathrm{C}$ & $29.93 \mathrm{C}$ \\
\hline 32 & $6.18 \mathrm{E}$ & $24.30 \mathrm{D}$ & $27.70 \mathrm{D}$ \\
\hline 35 & $7.17 \mathrm{E}$ & $25.75 \mathrm{D}$ & $29.18 \mathrm{C}$ \\
\hline 36 & $5.78 \mathrm{E}$ & $27.40 \mathrm{C}$ & $28.38 \mathrm{D}$ \\
\hline 37 & $6.63 \mathrm{E}$ & $35.10 \mathrm{~A}$ & $32.33 \mathrm{C}$ \\
\hline 38 & $8.57 \mathrm{D}$ & $29.80 \mathrm{~B}$ & $29.00 \mathrm{C}$ \\
\hline 39 & $6.75 \mathrm{E}$ & $31.58 \mathrm{~B}$ & $30.78 \mathrm{C}$ \\
\hline 40 & 11.77 D & $27.87 \mathrm{C}$ & $25.23 \mathrm{D}$ \\
\hline 41 & $6.93 \mathrm{E}$ & $27.23 \mathrm{C}$ & $26.57 \mathrm{D}$ \\
\hline 42 & $7.22 \mathrm{E}$ & $24.47 \mathrm{D}$ & $27.98 \mathrm{D}$ \\
\hline 43 & $3.90 \mathrm{E}$ & $22.42 \mathrm{D}$ & $20.17 \mathrm{E}$ \\
\hline 44 & $4.13 \mathrm{E}$ & $21.67 \mathrm{D}$ & $24.70 \mathrm{D}$ \\
\hline 45 & $5.90 \mathrm{E}$ & $31.13 \mathrm{~B}$ & $32.50 \mathrm{C}$ \\
\hline V.C. $(\%)$ & 28.89 & 11.29 & 11.42 \\
\hline General mean & 10.27 & 28.36 & 28.28 \\
\hline
\end{tabular}

* Equal letters between lines do not differ by the Scott-Knott test at $5 \%$ probability. 


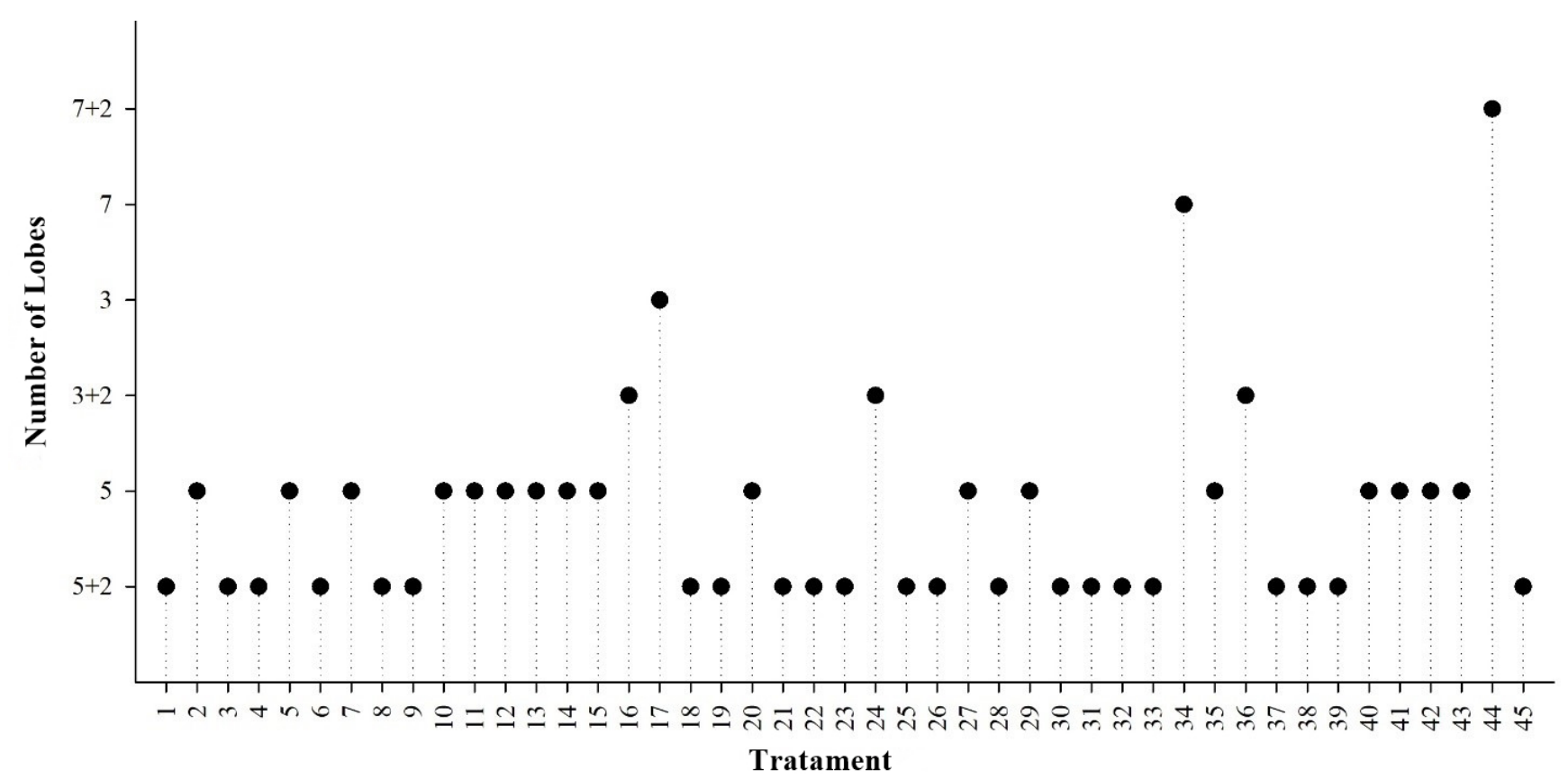

Figure 1. Number of lobes of Active Germplasm Bank fig accessions of the Faculty of Agricultural and Technological Sciences (FCAT / UNESP). Dracena / SP, 2017.
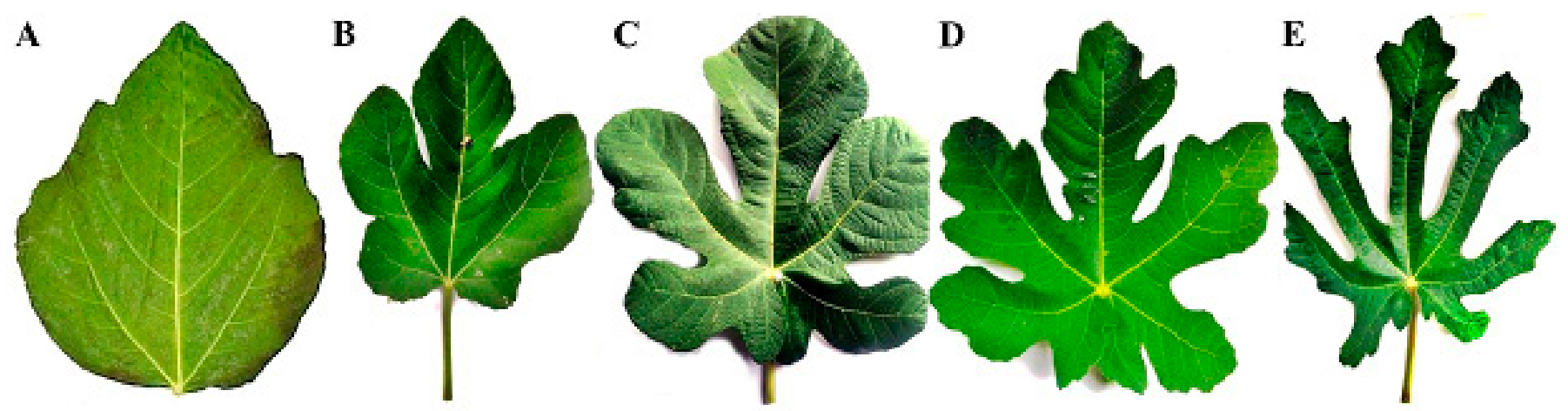

Figure 2. Leaves of accessions 17 (Troyano) (A), accessions 24 (Nazaret) (B), accessions 45 (Turco Fig) (C), accession 4 (Roxo-de-Valinhos) (D) and accession 44 (Preto de Piracicaba Fig) (E) characterizing respectively leaves with 3, 3 $+2,5+2,7$ and $7+2$ lobes. Dracena - SP, 2017.
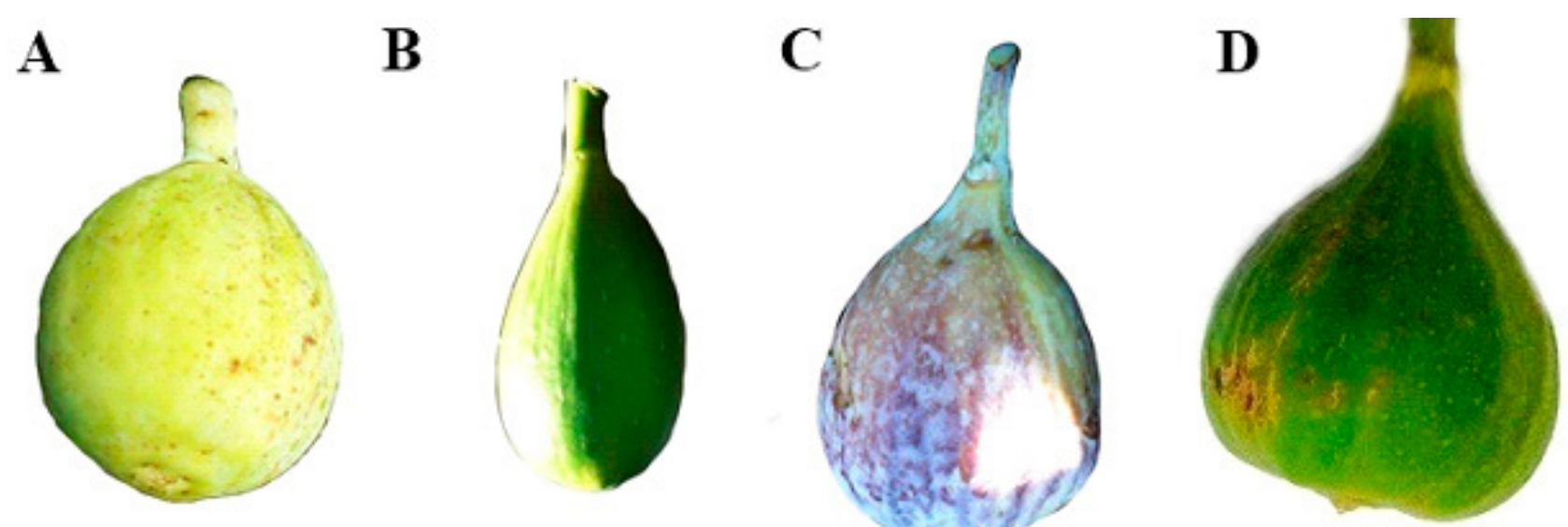

Figure 3. Fruit of accession 14 (Pingo-de-Mel) (A), accession 19 (Irradiated Plant 440) (B), accession 4 (Roxode-Valinhos) (C) and accession 8 (White Genova) (D) characterizing, respectively, oval, elongated, oblong pyriform and flattened fig fruits. Dracena - SP, 2017. 


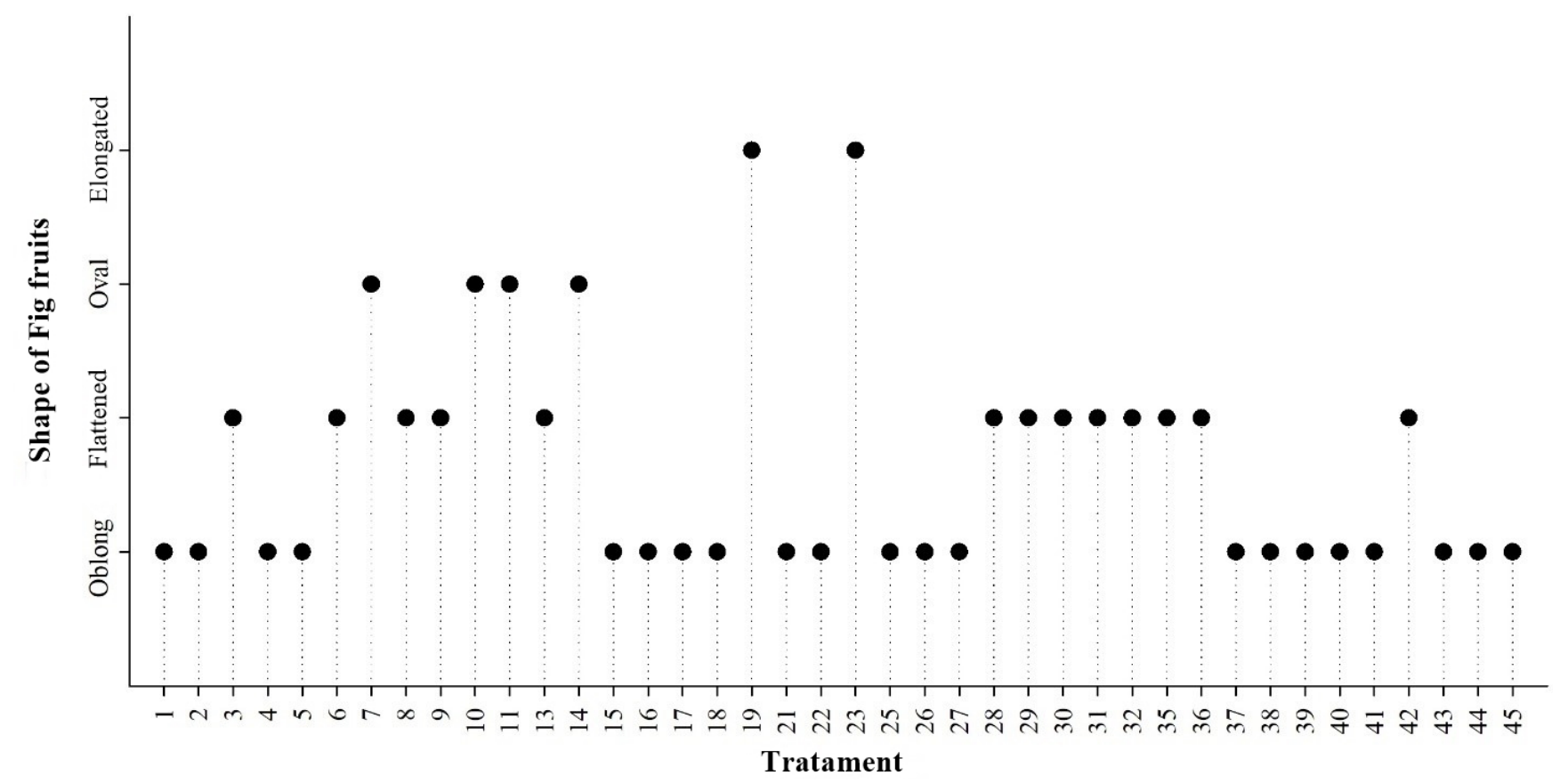

Figure 4. Shape of Fig fruits accessions. Dracena - SP, 2017.

A

B
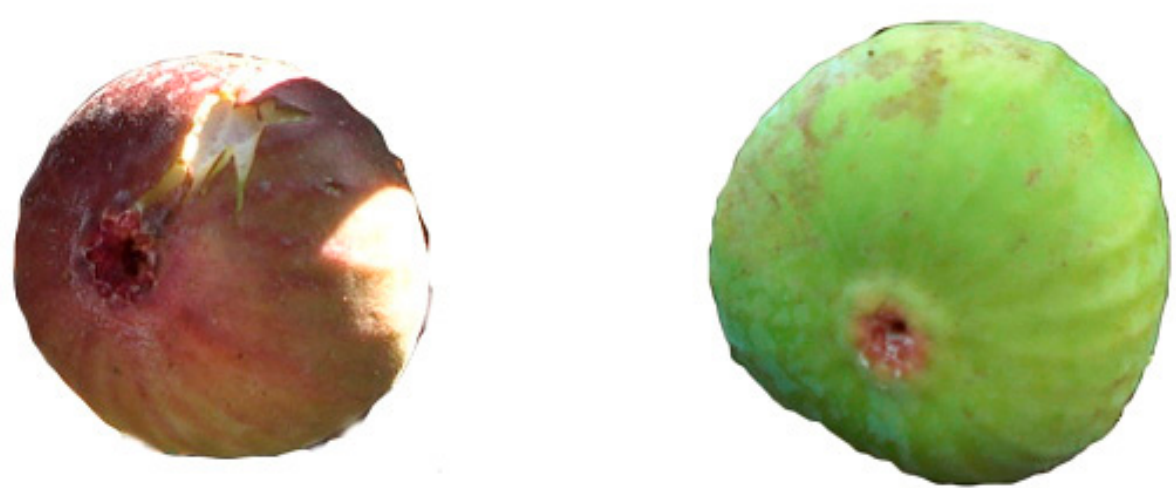

Figure 5. Fruit of accession 4 (Roxo-de-Valinhos) (A) and accession 14 (Pingo de Mel) (B) characterizing, respectively, open and closed fig tree ostiole. Dracena - SP, 2017. 


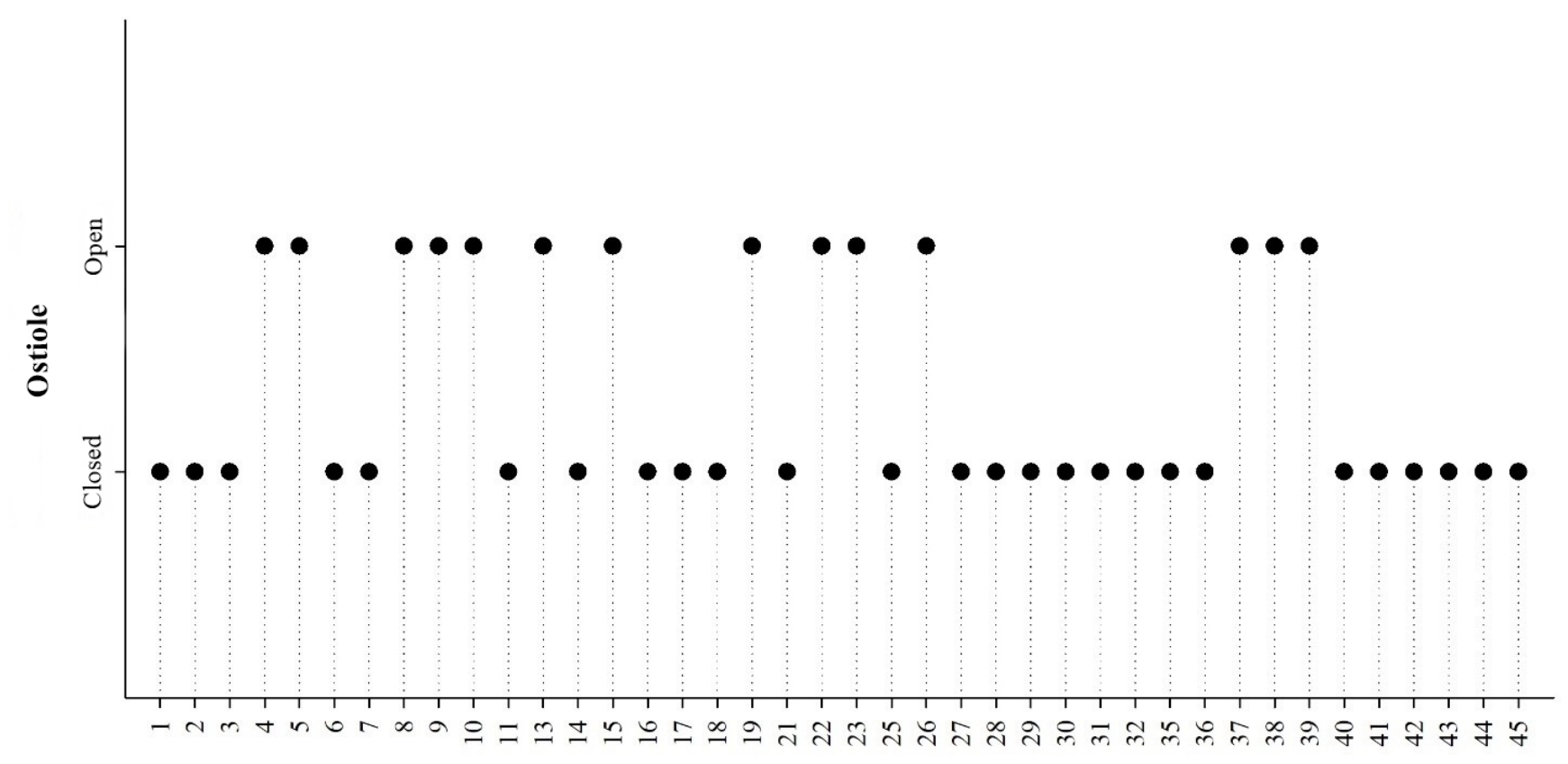

Tratament

Figure 6. Characteristic of the ostiole of fruits from Fig tree accessions. Dracena - SP, 2017.

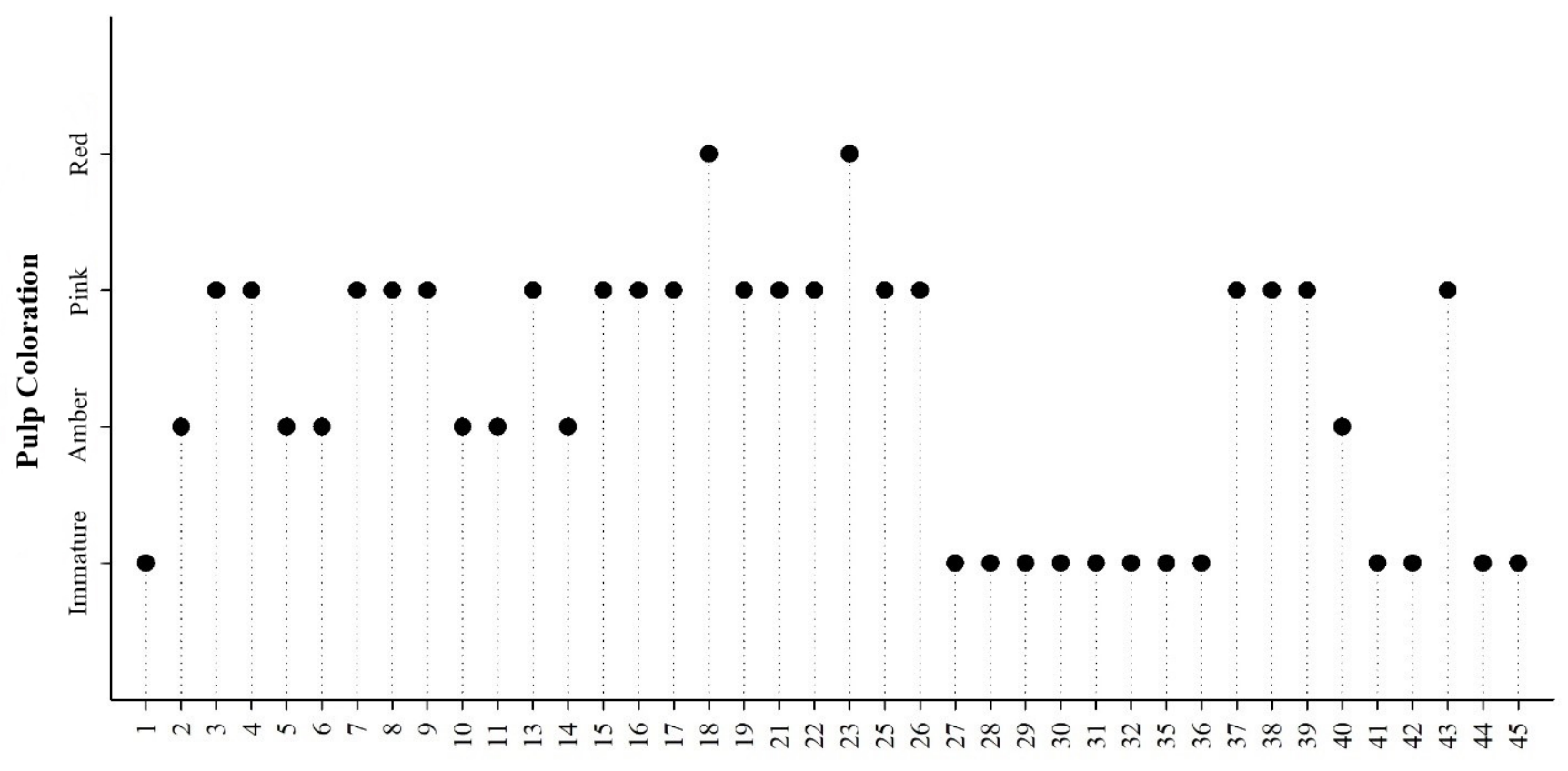

Tratament

Figure 7. Pulp coloration of fruits from Fig tree accessions. Dracena - SP, 2017. 
A

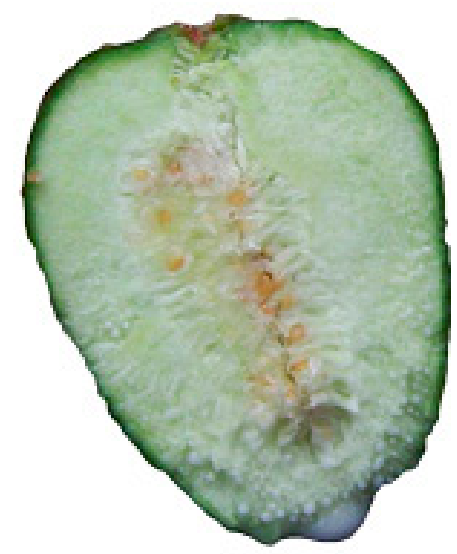

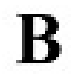

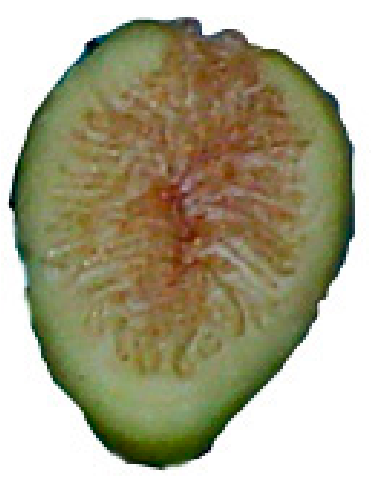

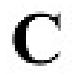

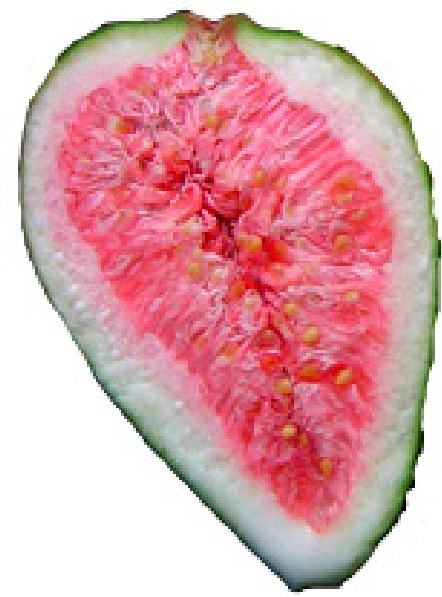

Figure 8. Fruit of accession 10 (Smyrna) (A), 14 (Pingo-de-Mel) (B) and accession 18 (Vermelho de Piracicaba Fig) (C) characterizing, respectively, immature fruit, amber and intense pink pulp fruit. Dracena - SP, 2017.

\section{Conclusion}

It was concluded that it was possible to characterize fig tree accessions through the morphological characteristics of leaves and fruits, identifying AGB with good adaptation to the region and, through the analysis of qualitative and quantitative features, it could be concluded that the most divergent accessions are 16 (Palestino), 17 (Troyano), 18 (Vermelho de Piracicaba Fig), 19 (Irradiated Plant 440), 21 (Irradiated Plant 189), 22 (Irradiated Plant 214), 23 (Irradiated Plant 301), 24 (Nazaret), 44 (Preto de Piracicaba Fig) and 45 (Turco Fig), with characteristics of agronomic interest, allowing the selection of features in order to subsidize conservation works, genetic improvement and crop production.

\section{Acknowledgments}

To the Faculty of Agrarian and Technological Sciences FCAT / UNESP and to the Foundation of Research Support of the State of São Paulo (FAPESP) for the financial assistance granted to the first author, process number 2016/20418-8.

\section{References}

ALJANE, F.; ESSID, A.; NAHDI, S. Improvement of Fig (Ficus carica L.) by Conventional Breeding and Biotechnology. In: AL-KHAYRI, J.M., JAIN, S.M.; JOHNSON, D.V. Advances in Plant Breeding Strategies: fruits. Basel: Springer, 2013. v. 3, p. 343-375.

ANDRADE, C. M. S.; VALENTIM, J. F.; CARNEIRO, J. C.; VAZ, F. A. Crescimento de gramíneas e leguminosas forrageiras tropicais sob sombreamento. Pesquisa Agropecuária Brasileira, v. 39, n.3, p. 263-270, 2004.

ARADHYA, M.K.; DIANNE VELASCO, E.S.; KOEHMSTEDT,A. Genetic structure and differentiation in cultivated fig (Ficus carica L.). Genetica, Dordrecht,v.138, n.6, p.681-694, 2010.

CARVALHO, J.M.F.C; ARAÚJO, S.S.; SILVA, M.A. Preservação e intercâmbio de germoplasma. Campina Grande: Embrapa Algodão, 2008. 24p. (Documento, 196)

CHEN, T.W.; NGUYEN, T.M.N.; KAHLEN, K.; STÜTZEL, H. Quantification of the effects of architectural traits on dry mass production and light interception of tomato canopy under different temperature regimes using a dynamic functional-structural plant model. Journal of Experimental Botany, Oxford, v.65, p.6399-6410, 2014. 
CHENU, K.; FRANCK, N.; DAUZAT, J.; BARCZI, J.F.; REY, H.; LECOEUR, J. Integrated responses of rosette organogenesis, morphogenesis and architecture to reduced incident light in Arabidopsis thaliana results in higher efficiency of light interception. Functional Plant Biology, Victoria, v.32, p.1123-1134. 2005.

CHITWOOD, D.H.; KLEIN, L.L.; O'HANLON, R.; CHACKO, S.; GREG, M.; KITCHEN, C.; MILLER, A.J.; LONDO, J.P.Latent developmental and evolutionary shapes embedded within the grapevine leaf. New Phytologist, Cambridge, v.210, p.343-55, 2016.

CHITWOOD, D.H.; OTONI, W.C. Morphometric analysis of Passiflora leaves: the relationship between landmarks of the vasculature and elliptical Fourier descriptors of the blade. GigaScience, Oxford, v.6, n.1, p.1-13, 2017.

DAUZAT, J.; CLOUVEL, P.; LUQUET, D.; MARTIN, P.Using virtual plants to analyse the light-foraging efficiency of a low-density cotton crop. Annals of Botany, London, v.101, p.1153-1166, 2008.

DIAS-FILHO, M.B. Physiologycal response of Solanumcrinitum Lam. to contrasting light environments. Pesquisa Agropececuária Brasileira, v. 32, p.789-796, 1997.

FALSTER, D.S.; WESTOBY, M. Leaf size and angle vary widely across species: what consequences for light interception? New Phytologist, Oxford, v.158, p.509-525, 2003.

FAOSTAT. Crops production. Rome: FAO, 2019. Disponível em: http://www.fao.org/faostat/en/\#data/QC/ visualize/figs. Acesso em: 25 abr. 2019.

FERRAZ, R.A. Propagação e desempenho agronômico de variedades de figueira (Ficus carica L.) com potencial de cultivo. 2017. Tese (Doutorado) - Faculdade de Ciências Agronômicas, Universidade Estadual Paulista, Botucatu, 2017.

FERREIRA, D. F.. Sisvar: a guide for its bootstrap procedures in multiple comparisons. Ciência e Agrotecnologia, Lavras, v.38, n.2, p.109-112, 2014.

FRANKHAM, R. Genetics and extinction. Biological Conservation, Oxford, v.126, p.131-140, 2005.

HE, S.L.; HOLLINGSWORTH, P.; YI, T.S.; LI, D.Z. Environmental and historical determinants of patterns of genetic differentiation in wild soybean (Glycine soja Sieb. et Zucc). Scientific Reports, Londres, v.6, p.22795, 2016.
HUANG, P.; FELDMAN, M.; SCHRODER, S.; BAHRI, B.A.; DIAO, X.; ZHI, H.; ESTEP, M.; BAXTER, I.; DEVOS, K.M.; KELLOGG, E.A. Population genetics of Setaria viridis, a new model system. Molecular Ecology, London, v.23, p.4912-4925, 2014.

LAMAS, L.; ELIAS, G.; PEREIRA, R.A.S. Comportamento agressivo em femeas de vespas polinizadoras (Hymenoptera: Agaonidae) de Ficus (Moraceae). In: CONGRESSO DE ECOLOGIA DO BRASIL, 9., 2009. São Lourenço. Anais [...]

MEDEIROS, A.R.M. Figueira (Ficus carica 1.) do plantio ao processamento caseiro. Pelotas: Embrapa, 2002. 16p. (Circular técnica, 35).

NIINEMETS, Ü. Photosynthesis and resource distribution through plant canopies. Plant, Cell and Environment, Oxford, v.30, p.1052-1071, 2007.

PAEZ, A.; GEBRE, G.M.; GONZALEZ, M.E.; TSCHAPLINKI, T.J. Growth, soluble carbohydrates, and aloin concentration of Aloe vera plants exposed to three irradiance levels. Environmental and Experimental Botany, v. 44, p. 133-139, 2000.

PALACE, M.; SULLIVAN, F.B.; DUCEY, M.; HERRICK, C. Estimating tropical forest structure using a terrestrial lidar. PLoS One, San Francisco, v.11, n.4, e0154115, 2016.

PEREZ, R.P.A.; DAUZAT, J.; PALLAS, B.; LAMOUR, J.; VERLEY, P.; CALIMAN, J.; COSTES, E.; FAIVRE, R. Designing oil palm architectural ideotypes for optimal light interception and carbon assimilation through a sensitivity analysis of leaf traits, Annals of Botany, London, v.121, n.5, p.909-926, 2018.

PLATT, A.; HORTON, M.; HUANG, Y.S.; LI, Y.; ANASTASIO, A.E.; MULYATI, N.W. The scale of population structure in Arabidopsis thaliana. PLoS Genetics, San Francisco, v.6, n.2, e1000843, 2010.

RAGA, A. Mosca-do-figo. In: REUNIÃO ITINERANTE DE FITOSSANIDADE DO INSTITUTO BIOLÓGICO, 7., 2002, Indaiatuba. Anais [...]. Campinas: Instituto Biológico, 2002. p.54-57.

RAGA, A.; SOUZA FILHO, M.F. DE Captura de Zaprionus indianus (Gupta) (Dip.: Drosophilidae) em frascos de plásticos com iscas alimentares na cultura do figo. Revista Agriculturas, Rio de Janeiro, v.78, n.3, p.323-329, 2003. 
RAIJ, B. van.; CANTARELLA, H.; QUAGGIO, J.A.; FURLANI,A.M.C. (ed.). Recomendações de adubação e calagem para o estado de São Paulo. 2.ed.rev. Campinas: IAC,1997. p.45-47 (Boletim Técnico, 100).

RAMALHO, M.A.P.; PINTO, C.A.B.P.; SANTOS, J.B. Genética na agropecuária. 5.ed. Lavras: Editora da UFLA, 2012. 566p.

RIGITANO, O. A figueira cultivada no Estado de São Paulo. 1955. Tese (Doutorado em Fitotecnia) - Escola Superior de Agricultura “Luiz de Queiroz", Universidade de São Paulo, Piracicaba, 1955.

RODRIGUES, M. G. F.; CORRÊA, L. S.; SANTOS, P.C.; TULMANN NETO, A. Seleção de clones de figueira cv. Roxo-de-Valinhos formados por gemas irrigadas. Revista Brasileira de Fruticultura, Jaboticabal, n.2, v.34, p.604611, 2012.

RODRIGUES, M.G.F.; MONTEIRO, L.N.H.;FERREIRA, A.F.A.; PAVAN, B.E.; BOLIANI, A.C. Caracterização morfológica de acessos de banco de germoplasma de figueira. In: CONGRESSO BRASILEIRO DE FRUTICULTURA, 25., 2017. Porto Seguro. Anais [...]. Campos dos Goytacazes: SBF, 2017.

SARLIKIOTI, V.; DE VISSER, P.H.B.; MARCELIS, L.F.M. Exploring the spatial distribution of light interception and photosynthesis of canopies by means of a functional-structural plant model. Annals of Botany, London, v.107, n.5, p.875-883, 2011.

SILVA, D. da; HAN, L.; FAIVRE, R.; COSTES, E. Influence of the variation of geometrical and topological traits on light interception efficiency of apple trees: sensitivity analysis and metamodelling for ideotype definition. Annals of Botany, London, v.114, p.739-752, 2014 .
SILVA, L.; MARTINS, C.C.; MACHADO, C.G.; NAKAGAWA, J. Estádios de colheita e repouso pós-colheita dos frutos na qualidade de sementes de mamoneira. Revista Brasileira de Sementes, Londrina, v.31, n.1, p.50-59, 2009.

SONG, Z.C.; MIAO, H.; ZHANG, S.; WANG, Y.; ZHANG, S.P.; GU, X.F.. Genetic Analysis and QTL Mapping of Fruit Peduncle Length in Cucumber (Cucumis sativus L.). PLoS ONE, San Francisco, v.11, n.12, e0167845, 2016.

STOJANOVIĆ M, PEZO L, LAČNJEVAC Č, MIHAJLOVIĆ M, PETROVIĆ J, MILOJKOVIĆ J. Biometric approach in selecting plants for phytoaccumulation of uranium. International Journal of Phytoremediation, Boca Raton, v.18, n.5, p.527-533, 2016.

TAKENAKA, A. Effects of leaf blade narrowness and petiole length on the light capture efficiency of a shoot. Ecological Research, Oxford, v.9, p.109-114, 1994.

VALOIS, A.C.C.; NASS, L.L.; GOES, M. Conservação "ex situ" de recursos genéticos vegetais. In: NASS, L.L.; VALOIS, A.C.C.; MELO, I.S.; VALADARES-INGLIS, M.C. (ed.). Recursos genéticos \& melhoramento: planta. Rondonópolis: Fundação MT, 2001. p.123-158.

VENDRUSCOLO, C.T. Aceitabilidade de figo (Ficus carica L.) cv. Roxo de Valinhos desidratado com açúcar e SO2. 1988. Dissertação (Mestrado em Ciência e Tecnologia Agroindustrial) - Universidade Federal de Pelotas, Pelotas, 1988. 